Article

\title{
Ridership and the Built-Form Indicators: A Study from Ahmedabad Janmarg Bus Rapid Transit System (BRTS)
}

\author{
Md Rabiul Islam ${ }^{1, *}$, Mark Brussel $^{2}$, Anna Grigolon ${ }^{2}$ and Talat Munshi ${ }^{3}$ \\ 1 Department of Urban and Regional Planning, Chittagong University of Engineering and Technology, \\ Chittagong 4349, Bangladesh \\ 2 Department of Urban and Regional Planning and Geo-Information Management (ITC), University of Twente, \\ 7500 AE Enschede, The Netherlands; m.j.g.brussel@utwente.nl (M.B.); a.b.grigolon@utwente.nl (A.G.) \\ 3 UNEP-DTU Partnership, Department of Management Engineering, Technical University of Denmark, \\ Marmorvej 51, 2100 København Ø, Denmark; tamu@dtu.dk \\ * Correspondence: rabiul.buet05@gmail.com; Tel.: +880-172-2015-521
}

Received: 20 August 2018; Accepted: 18 September 2018; Published: 20 September 2018

\begin{abstract}
Although the Janmarg (people's way) Bus Rapid Transit System (BRTS) system in Ahmedabad, India, achieved worldwide accolades since its introduction, it has not reached its expected ridership. In analyzing ridership, research shows that external factors of BRTS such as built-form indicators have a potentially greater effect on ridership than its internal factors. In order to assess the ridership of the Janmarg BRTS, a methodology was developed based on built-form indicators that were quantified using the "5D" approach. The use of appropriate geo-information science (GIS) techniques helped to analyze the built-form spatial data effectively. The calculated built-form indicators were used as inputs in a regression analysis. The consulted literature suggests a relationship between built-form indicators and ridership. However, in the present study this relationship was not confirmed. Moreover, land-use diversity, road connectivity, and job accessibility by BRTS were found to be relatively low. Several policy recommendations were suggested along the BRTS corridors in line with the existing policy such as the utilization of full Floor Space Index potential, the application of Transit Oriented Development strategies and the integration with non-motorized modes to increase the accessibility to the most important job locations.
\end{abstract}

Keywords: BRTS; ridership; 5D built-form indicators; GIS; Transit Oriented Development

\section{Introduction}

Bus Rapid Transit (BRT) systems have been adopted in many cities worldwide due to their unique characteristics of mass transit for promoting sustainable mobility and as a key strategy for resolving traffic related problems, mainly congestion [1]. BRT aims to reduce automobile usage and thus make cities less liable to environmental damage, for example by reducing vehicle emissions [2].

The city of Ahmedabad, the seventh largest city in India and the largest in the state of Gujarat, is experiencing rapid economic growth and urbanization and is emerging to be one of the main urban centers of India. It is a compact city with a mixed pattern of land use across its 490 square $\mathrm{km}$ area. It has a population of more than 5.6 million and is expected to grow up to 11 million by 2035 [3,4].

To fulfill the transport demand of this large population, a substantial number of motorized vehicles are in use. The city has registered 1.4 million vehicles, a number which is growing at a rate of $8-10 \%$ (0.1 million) per year. This rapid growth in motorized vehicles, where two-wheelers (motor scooters) account for $73 \%$ of the total share, four-wheelers (cars) and three-wheelers account for around $12.5 \%$ 
and $5.01 \%$ respectively, has resulted in congestion and air pollution. As a result, the city of Ahmedabad was featured in the top three cities of a list of 88 critically polluted cities of India [5].

Furthermore, the city has also experienced an increasing accident rate. A study conducted in 2008 in cooperation with Ahmedabad Municipal Corporation (AMC), Ahmedabad Urban Development Authority (AUDA), and CEPT University indicated that out of 2605 accidents $9.5 \%$ were fatal. In $42 \%$ of cases the victims were cyclists and in $19 \%$ percent of cases they were pedestrians. Besides, due to reducing resources and operational inefficiencies, the Ahmedabad Municipal Transport Service (AMTS), the only public transport that is run by the city authority, has reduced its fleet size from 724 to 540 buses, while the number of passengers also dropped to 0.35 million from 0.62 million [6].

In order to resolve those issues along with reducing automobile dependence and keeping pace with the increasing demand, the city has introduced the Janmarg Bus Rapid Transit System (BRTS). Janmarg is a median-way BRT development, which was designed as a complementary mode for the AMTS. The project was to be undertaken in two phases, which are already in operation [6].

Since its launch, Janmarg BRTS has earned worldwide acclaim and is considered to be a role model in the public transportation sector in India. Janmarg BRTS is the first BRT system in India that has achieved a "Silver" rating, as it scored between 70 and 84 on a scale of 100 in the BRT standard score developed by the Institute for Transportation and Development Policy (ITDP). It has also managed quite a high ridership (passengers per day) as statistics of AMC in 2011 show that on average 0.13 million passengers use this BRT service daily and the daily revenue is about 0.75 million Indian Rupee (INR) [5].

Besides, its modal share has also increased significantly. A survey was carried out by Mahadevia in 2012 on BRTS to observe the modal shift of BRTS from other modes where it was found that $47 \%$ of BRTS users shifted from the AMTS which is also running along the BRTS corridors. Another $25 \%$ of users shifted from auto rickshaws, $11.7 \%$ from a private vehicle, and only $2.3 \%$ from walking and cycling. The remaining $13 \%$ of users have been encouraged to travel due to its better service quality. The modal share has reduced significantly for other modes, helping to reduce the use of motorized modes $[7,8]$.

Despite having a worldwide reputation, some contentious issues have been raised towards Janmarg BRTS. In the same study mentioned above, some of the issues were pointed out: the level of service meets only $1 \%$ of travel demand of 30 billion passenger km per year. Moreover, only $27 \%$ of BRTS users are women, only 3\% of trips are made by the low-income groups of the society, it has not been fully integrated with AMTS, and footpaths and cycle tracks have not been fully designed and constructed along all corridors thus hampering safety and access of the pedestrians and cyclists to BRTS stations $[7,8]$. Although BRTS has created new demand and enhanced people's mobility, it has failed to develop dedicated commuters of working-class people [9]. A case study by Damor, Kumara, \& Hajiani (2014) found that in the corridors Kalupur Station to Town Hall Station, commuters are not using BRTS, rather they prefer AMTS and other available modes. The main reason is that commuters find it difficult to access to BRTS due to a lack of provision for pedestrian crossing. The high fare structure of BRTS for short distances compared to AMTS was also reported as one of the reasons [10].

The issues discussed above directly or indirectly hamper the ridership (passengers per day) performance. In the detailed report on Janmarg BRTS, which was fully planned and designed by the technical team from CEPT University, one of the visions was to ensure full accessibility of Janmarg BRTS to all classes of people [11]. Besides, an increase of ridership can help in reducing the automobile dependence (two-wheelers, cars), which has impacts on congestion reduction and on pollution reduction [12,13]. In brief, it can be concluded that Janmarg BRTS could not achieve its maximum ridership yet. Ridership usually refers to the number of passengers per day using the transit services and is also expressed in other units such as passenger per vehicle kilometer, passenger per day per kilometer, and so on. The performance indicators for ridership can be of two types: internal, which is related with the service quality (comfort), pricing, operation characteristics (speed, frequency) of the system, and external, which refers to the outside factors of the system along the transit corridors 
such as local economic condition, population and employment growth, and so on [14]. According to the Transit Cooperative Reseach Program (2007), external factors of transit system have a potentially greater effect on ridership than its internal factors [15]. For instance, population density or local economic growth of the region has more influence on transit ridership than any internal service characteristics of transit like comfort, speed, and so on. The external factors from the transit ridership framework adopted from Mineta Transportation Institute (2002) can be synonymously used with the location and neighborhood attributes: population density, employment density, total urban density, street connectivity index, and distance to the nearest BRT stop-given by Cervero, Murakami, \& Miller (2010) $[14,16]$.

The conventional four-step transportation model which was developed in the 1950s later included the built-form indicator in the modeling process to analyze the relationship between travel behavior and built form [17]. At first, Stopher (1992) and Peng, Dueker, Strathman, \& Hopper (1997) modeled transit demand and supply where they considered some neighborhood variables such as land-use mix, population and employment density $[18,19]$. They found that ridership depends partly on land-use mix and density. In this paper, we are working with built-form indicators, as originally developed by Cervero \& Kockelman (1997), the so-called "3 D's"—-density, diversity, and design [20]. Later, these were extended with two new indicators: 'distance to transit stop' and 'destination accessibility' [21]. These five indicators make up the commonly used " $5 \mathrm{D}$ 's" and each of them will be described in brief in the next section.

The objective of this paper is, therefore, to assess ridership performance of Janmarg BRTS based on built-form indicators, focusing on the relation between urban built-form characteristics and ridership. The paper is structured as follows: the next section will discuss commonly used built-form indicators and methods to measure them. Next, the literature on transit ridership and the relation with built form will be reviewed. The study area will be described, followed by the description of the data and methods. Results are then analyzed and conclusions are drawn.

\section{5D Built-Form Indicators}

\subsection{Density}

Density usually refers to the number of people or jobs per unit of area [22,23]. The effects of density on travel demand have long been recognized and remain used in travel behavior study. Higher densities are related with higher transit use, less automobile use, and an emphasis on walking and cycling, the reason being that public transit can be efficiently operated in high density areas and offers advantages over car travel [20,24-26]. Another reason for the positive and significant relationship between population density and transit ridership at the station level is that residents living close to the station are more likely to be travelling by transit [27]. Parsons Brinckerhoff Quade \& Douglas Inc. (1996) has also found that ridership increases exponentially with the increase of employment along the transit corridors [28]. Munshi (2013) has also observed that the concentration of growth along the corridors tends to increase transit ridership by reducing the travel distance for commuters from their origin to the transit stop. A short distance usually encourages commuters to walk or use non-motorized modes to access to the stop [29].

Popular measures of density are population density, household density, residential density, job density, and commercial and service density [29]. Since workers are the everyday users of transit systems, employment density is considered as a most prominent indicator for transit ridership, particularly as often the majority of transit movements happen in the peak hours.

Density is usually measured per unit of area. We use the following measures:

Residential density,

$$
D_{r}=\frac{P}{A}
$$


Employment density,

$$
D_{e}=\frac{J}{A}
$$

where, $P$ and $J$ refer to the total number of people and jobs respectively and $A$ refers to an area measured in acre.

\subsection{Diversity}

Gao, Mokhtarian, \& Johnston (2008) have demonstrated that people in residential areas with higher job accessibility are more likely to own fewer automobiles and show increased use of transit which is also consistent with the study output by Kitamura et al. (1997) [24,30]. In general, a higher mixing of compatible land uses increases the opportunities for commuters to access different associated functions within a short distance. More commercial and retail outlets around transit stations would encourage people not to use private automobiles and help people to shop for their daily necessities on their way back home from work [4]. Moreover, a proper mix of land use also helps to generate new transit demand [31]. On the other hand, homogeneous land use induces sprawl growth which enhances automobile ownership among the residents and simultaneously reduces transit use.

Land-use diversity measures the degree of proximity among different land uses e.g., residential, commercial, industrial, institutional and recreational. According to Boarnet (2011), the entropy index is the most commonly-used index for land-use diversity [32]. It computes the heterogeneity of land within a given area of interest. The original formula was developed by Frank \& Pivo (1994) which was later simplified [33]. The computation is quite simple for entropy as it takes vector data as input. The resulting value of the entropy index is between 0 and 1 , where 0 represents the total homogeneity of land and 1 represents the total heterogeneity. The mathematical expression of entropy index is as follows.

$$
\text { Entropy index }=-\sum_{j} P_{j} \times \ln \left(p_{j}\right) / \ln (J)
$$

where $P_{j}=$ Proportion of land-use category $j$ within a specified buffer zone (service area); $J=$ number of land-use categories.

However, the measure of entropy index is limited within a neighborhood area, typically having a buffer zone ranging from a quarter to a half mile [20]. So it may not be suitable for a neighborhood with more than a half-mile radius. Recognizing the limitation of the entropy index, Cervero \& Kockelman (1997) developed a new diversity index which is not influenced by the size of the neighborhood and is a relatively better measure for diversity [20]. It calculates the land-use diversity using the 8-cell neighborhood rule where the corresponding interaction of land uses with one another are considered. Similar to the entropy index, the value of the dissimilarity index ranges from 0 to 1 . The only difference is that it works on a raster data format. According to Cervero \& Kockelman (1997), the dissimilarity index provides more accurate information of land-use mixture than entropy because the entropy index is unable to identify the sprawling pattern of land [20].

$$
\text { Dissimilarity index }=\left\{\left[\sum_{j}^{k} \sum_{l}^{8}\left(\frac{X_{l}}{8}\right)\right] / K\right\}
$$

where, $K=$ number of actively developed grid-cells measured in an acre, and $X_{l}=1$ if the land-use category of neighboring (immediate contact) grid-cell differs from grid-cell $j$ measured in an acre (0 otherwise).

\subsection{Design}

In the 5D concept, the design is specified to only road connectivity. Road connectivity denotes the degree of a road which is connected towards destinations. A poorly-connected road network with many cul-de-sacs, i.e., dead-end roads, diminishes accessibility to destinations and increases 
commuting distance. On the other hand, increased connectivity reduces the travel distance which enhances the walking environment [34].

Connectivity can be measured using various indices, which are street density, intersection density, the proportion of four-way intersections, and proportion of dead-end streets [35,36]. Ewing \& Cervero (2010) have an emphasis on the measure of street connectivity index and intersection density [37]. There are also some popular measures for road connectivity like Beta index and Gamma index as extracted from the graph theory by Rodrigue, Comtois, \& Slack (2006) [38]. The beta index is similar in operation with the street connectivity index as proposed by Ewing \& Cervero (2010) [37].

$$
\begin{aligned}
\text { Beta index, } \beta & =\frac{e}{v} \\
\text { Gamma index, } \gamma & =\frac{e}{3(v-2)}
\end{aligned}
$$

where $e$ and $v$ refer to the edges (link) and vertex (node) respectively.

On the other hand, intersection density is determined using the road network taking into account the true intersection having three or more links [16].

$$
\text { Intersection Density }=\frac{T I}{A}
$$

where, $T I=$ number of true intersections having three or more links, and $A=$ land area in an acre.

\subsection{Destination Accessibility}

In the 5D concept, accessibility is measured in terms of destination accessibility. Destination accessibility is usually measured in terms of the number of jobs accessible within a given distance or time threshold. An area in a city from where a maximum number of jobs are accessible, such as the city center, will have locational advantages to reside in. Higher job accessibility from an area will definitely have an impact on transit use of that area.

We applied a gravity-based measure which included all possible destinations considering a distance decay function which is analogous to Newton's law of gravitation: "the weight of each opportunity is inversely proportional to the square of the travel time or travel distance required to reach that opportunity" [39]. Most researchers suggest that "a negative exponential weighting function is a more accurate representation" which is more substantial to present the outcome [39]. The equation chosen for the gravity based measure is as follows:

$$
\text { Accessibility index, } A I_{i}=\sum_{j}\left[j o b s_{j} * e^{\left(-v t i m e_{i j}\right)}\right]
$$

where, $j o b s_{j}=$ Number of jobs in zone $j$, time $=$ network travel time, $i=$ residential zone, and $j=$ employment zone and $v=$ gamma coefficient of variable 'time' [40].

\subsection{Distance to Transit Stop}

"Distance to transit stop is usually measured as an average of the shortest route from the residences to the nearest stop in an area" [37]. Alternatively, it is defined as the access and egress distance an individual has to travel to and from a transit stop. The longer the distance an individual has to travel to or from a transit stop, the lower the chance of using a specific service [29]. The most used measure is the distance between transit stops or the number of stations per unit of the area [37].

\section{Prior Studies on Ridership}

Numerous studies have been performed on ridership but very few considered built-form indicators as explanatory variables. Two reasons can be identified behind this: firstly, it is a somewhat 
new idea, which was first published in 2001 [21]. Secondly, most of the studies have compared the ridership performance based on service and station characteristics among BRT systems across different cities or countries where the use of built-form indicators may not be significant enough in that scale [41,42]. Few studies have included some of the built form indicators that are found to be significant with ridership. Those studies are outlined as follows in Table 1.

Table 1. Ridership studies showing the use of built-form indicators.

\begin{tabular}{|c|c|c|c|c|}
\hline \multirow{2}{*}{ Study Source } & \multirow{2}{*}{$\begin{array}{c}\text { Dependent } \\
\text { Variable (unit) }\end{array}$} & \multicolumn{2}{|c|}{ Independent Variable } & \multirow{2}{*}{ Sample Size } \\
\hline & & Built-Form Variable & Qualitative Variable (Dummy) & \\
\hline $\begin{array}{l}\text { (Estupiñán \& } \\
\text { Rodríguez, } \\
\text { 2008) [43] }\end{array}$ & $\begin{array}{l}\text { Daily boarding per } \\
\text { station }\end{array}$ & $\begin{array}{l}\text { Land-use index, density, } \\
\text { road density, sum of } \\
\text { intersection }\end{array}$ & $\begin{array}{l}\text { Station characteristics and } \\
\text { perception about safety, clean, } \\
\text { pedestrian friendly, bike friendly } \\
\text { as extracted from the user }\end{array}$ & $\begin{array}{l}68 \text { stations of } \\
\text { Bogota Bus Rapid } \\
\text { Transit (BRT) }\end{array}$ \\
\hline $\begin{array}{l}\text { Kuby, } \\
\text { Barranda, \& } \\
\text { Upchurch, } \\
\text { 2004) [44] }\end{array}$ & $\begin{array}{l}\text { Average weekday } \\
\text { boarding }\end{array}$ & $\begin{array}{l}\text { Number of employment and } \\
\text { population within walking } \\
\text { distance, station spacing }\end{array}$ & $\begin{array}{l}\text { Station and city-wide dummy } \\
\text { variable }\end{array}$ & $\begin{array}{l}268 \text { light-rail } \\
\text { stations in nine US } \\
\text { cities }\end{array}$ \\
\hline $\begin{array}{l}\text { (Cervero et al., } \\
\text { 2010) [16] }\end{array}$ & $\begin{array}{l}\text { Average daily } \\
\text { boarding }\end{array}$ & $\begin{array}{l}\text { Population density, distance } \\
\text { to nearest BRT stop }\end{array}$ & $\begin{array}{l}\text { Service and station dummy } \\
\text { attributes }\end{array}$ & $\begin{array}{l}69 \text { stations of the } \\
\text { BRT in Los Angeles }\end{array}$ \\
\hline $\begin{array}{l}\text { (Durning \& } \\
\text { Townsend, } \\
\text { 2015) [45] }\end{array}$ & $\begin{array}{l}\text { Average daily } \\
\text { boarding }\end{array}$ & $\begin{array}{l}\text { Population density, } \\
\text { intersection density, } \\
\text { commercial site density, } 3 \\
\text { land-use variables }\end{array}$ & $\begin{array}{l}\text { Parking space, bus connection, } \\
\text { transfer station }\end{array}$ & $\begin{array}{l}342 \text { rail stations in } \\
\text { Canada }\end{array}$ \\
\hline $\begin{array}{l}\text { (Currie \& } \\
\text { Delbosc, 2013) } \\
{[46]}\end{array}$ & $\begin{array}{l}\text { Boardings/Veh-Km } \\
\text { (BVK) }\end{array}$ & $\begin{array}{l}\text { Residential density, } \\
\text { employment density, stop } \\
\text { spacing \%, accessible \%, } \\
\text { segregated right-of-way }\end{array}$ & $\begin{array}{l}\text { Integrated fares, capacity } \\
\text { (category) }\end{array}$ & $\begin{array}{l}101 \text { service routes } \\
\text { (BRT, Light Rail } \\
\text { Transit (LRT) and } \\
\text { Streetcar) }\end{array}$ \\
\hline
\end{tabular}

A BRT study in Bogota developed a ridership model with an overall statistical fit of $R^{2}=0.45$ in which road connectivity does not show significance. However, existing density and diversity work as a barrier to car uses which are consistent with station boarding at the $5 \%$ level [43]. This study is also complying with a BRT study in seven Latin American cities where a high mixture of land uses including institutional uses and public facilities are positively associated with ridership [47]. Similarly, in Light Rail Transit (LRT) study in the USA, a ridership model with a good $\mathrm{R}^{2}$ value of 0.727 indicates that a total number of employment and population within walking distance from station area are positively associated with boarding at the 5\% level [44]. BRT ridership study in Los Angeles also shows a high statistical fit of 0.952 where population density and the combination of both population density and employment density (total urban density) within $\frac{1}{2}$ mile of a bus stop are positively influencing ridership [16]. Moreover, direct ridership model of eight rail rapid transit systems in Canada fits with a value of 0.8097 where population density, employment density (commercial site density), land-use mixtures including commercial ratio, government-institutional ratio and residential ratio are having a significant positive relationship with ridership [45].

\section{Study Area Profile}

Ahmedabad is one of the blooming cities and an important industrial center in India. It contributes to $17 \%$ of the state (Gujarat) income [48]. In addition, "Ahmedabad is the home of several scientific and educational institutions with regional, national and global importance. The western part of the city has developed as a mainly high-income residential area, and major institutional area whereas the eastern part has the major industrial estates. For this reason, the traffic flow is very heavy from west to east in the morning and vice-versa in the evening which causes serious traffic congestion in the morning and evening peak periods" [49]. Consequently, the air pollution has become severe [49].

The city transportation system is largely dependent on roadway systems. The city road network is composed of five ring roads and 17 radial roads. "Ahmedabad is well connected by an expressway, several national and state highways, the broad gauge and meter gauge railways" [12]. As mentioned 
earlier, Janmarg BRTS was developed in two phases. The first phase of the project covered $58.3 \mathrm{~km}$ whereas, in phase 2, attempts were made to complement phase $1(30.5 \mathrm{~km})$ by making more areas accessible. The outlying suburbs which were developing rapidly were also connected by BRTS network.

Overall, twelve BRT trunk routes have been identified, which were structured in an integrated way to operate the transit services. Figure 1 shows the major BRT trunk routes along with their stations.

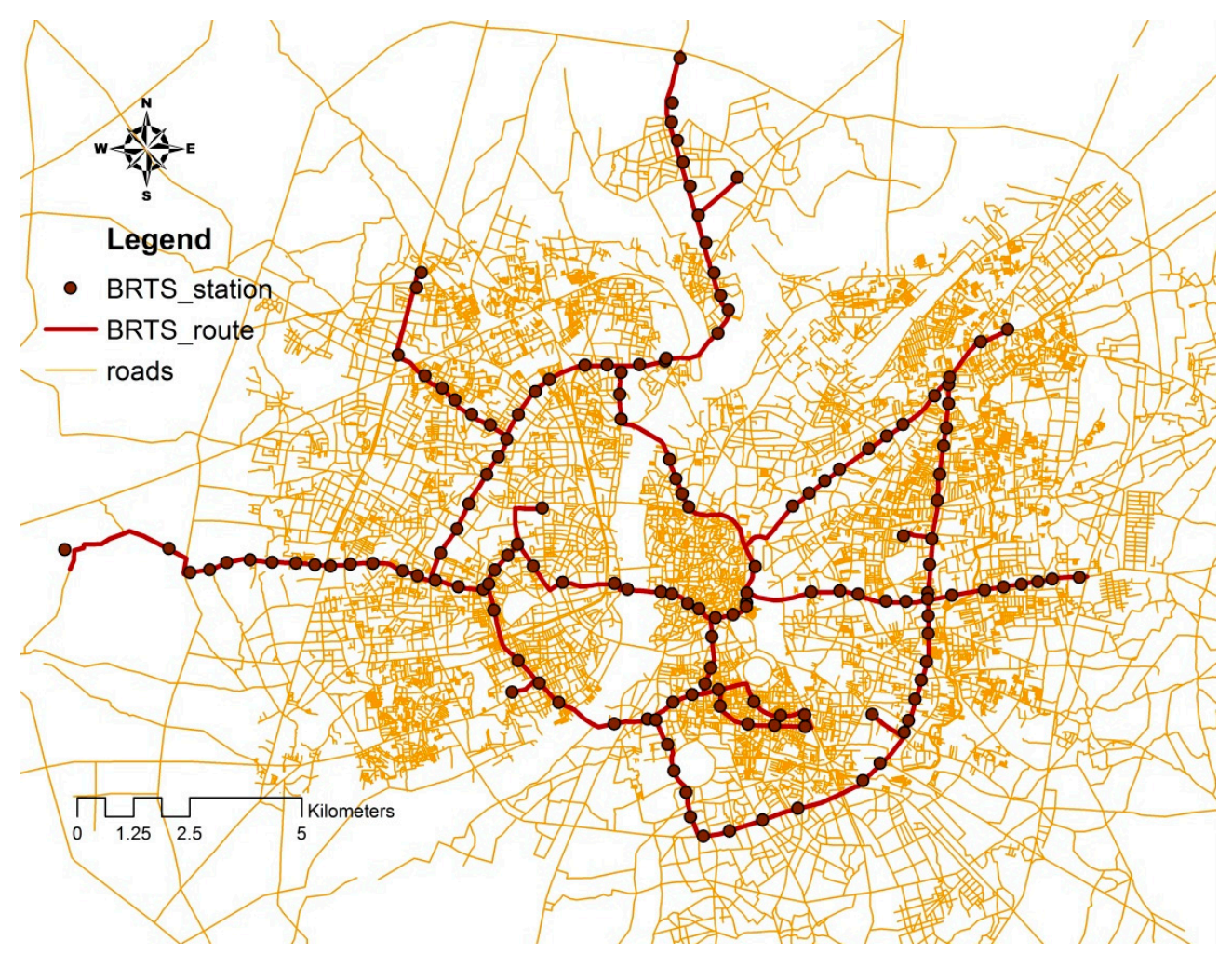

Figure 1. Map showing the major Bus Rapid Transit (BRT) trunk routes.

\section{Data and Methods}

The data used for this study are a combination of built form data in GIS format, which has been mostly derived from secondary sources from 2008-2013 and boarding data (ridership) of each station was extracted from July 2015. July was taken as a representative month, as the available nine months (From January 2015 to September 2015) boarding data had similar characteristics as seen from the Supplementary Material 'Passenger OD Jan to Sept 2015.xlsx'. As the main area of interest in Ahmedabad is already a built-up city, over these years the $5 \mathrm{D}$ built-form indicators have not been changing so much. If changed, it is assumed that the growth followed the same rate over time. The used data is summarized in Table 2. For detailed information about the data, see the Supplementary Material.

Different built-form indicators have already been discussed along with their corresponding measures. Some relevant literatures on ridership have also been reviewed. Now it intends to operationalize those concepts in this BRTS ridership study. Prior to that, the unit of analysis for this study needs to be selected. 
Table 2. Available data for the spatial analysis.

\begin{tabular}{llll}
\hline \multicolumn{1}{c}{ GIS Data File } & \multicolumn{1}{c}{ Type } & \multicolumn{1}{c}{ Purpose } & \multicolumn{1}{c}{ Source } \\
\hline $\begin{array}{l}\text { Population (at } \\
\text { TAZ }{ }^{1} \text { level) }\end{array}$ & $\begin{array}{l}\text { Polygon (spatial } \\
\text { and non-spatial) }\end{array}$ & $\begin{array}{l}\text { To determine the population density for } \\
\text { each station catchment }\end{array}$ & (Khanna, 2009) [49] \\
\hline Job (block) & $\begin{array}{l}\text { Square block } \\
\text { (polygon) }\end{array}$ & $\begin{array}{l}\text { To measure the job density for each station } \\
\text { catchment }\end{array}$ & (Munshi, 2013) [29] \\
\hline polyline & $\begin{array}{l}\text { To create the station catchment following } \\
\text { the network distance and to determine the } \\
\text { road connectivity }\end{array}$ & (Munshi, 2013) [29] \\
\hline Land use & polygon & $\begin{array}{l}\text { Provides information regarding different } \\
\text { land uses which will be used for diversity } \\
\text { measure }\end{array}$ & (Bajracharya, 2008) [50] \\
\hline BRTS route & polyline & $\begin{array}{l}\text { Job accessibility by Bus Rapid Transit } \\
\text { System (BRTS) following this route will be } \\
\text { measured }\end{array}$ & $\begin{array}{l}\text { Ahmedabad Janmarg } \\
\text { Limited, 2015 }\end{array}$ \\
\hline BRTS station & Point & $\begin{array}{l}\text { Information regarding station location from } \\
\text { which the catchment will be determined }\end{array}$ & $\begin{array}{l}\text { Ahmedabad Janmarg } \\
\text { Limited, 2015 }\end{array}$ \\
\hline $\begin{array}{l}\text { Total monthly } \\
\text { boarding (July, 2015) }\end{array}$ & $\begin{array}{l}\text { Excel format } \\
\text { (non-spatial data) }\end{array}$ & $\begin{array}{l}\text { This data will be used as a dependent } \\
\text { variable in the regression analysis }\end{array}$ & $\begin{array}{l}\text { Ahmedabad Janmarg } \\
\text { Limited, 2015 }\end{array}$ \\
\hline
\end{tabular}

${ }^{1}$ Transport Analysis Zone, the zoning system defining units of analysis used for travel household surveys.

\subsection{Analysis Unit}

The station is considered to be the unit of analysis for this study. A station level analysis is more appropriate than a route or route segment analysis, as ridership is measured at stations and not at routes. However, it requires more detailed data at the station level $[19,43]$.

The service area around each transit station needs to be identified. The service area (catchment area) around a transit station is generally defined "as the area from which potential riders are drawn". To determine the service area, most researchers depend on the willingness of people to walk or travel to and from a stop. Some researchers have empirically evaluated the walking distance to transit stops based on the data derived from user surveys [51-54]. They have concluded that a one-quarter mile service area from the transit stop would not capture all potential users while a larger service area will be an overestimation of the number of potential users if distance decay function is not explicitly considered. Moreover, estimation of a larger service area will often get a biased result because increasing travel distance to stop tends to shift the commuters to motorized mode [55].

Regarding this study, a 10 min walking distance for both access and egress was chosen which was derived from the BRTS user survey, which was conducted in 2015. It was found that almost $65 \%$ of the potential BRTS users access to and from a station within $10 \mathrm{~min}$ by walking. This $10 \mathrm{~min}$ walking distance buffer will, therefore, be drawn along the road network to identify the catchment area for each BRTS station (151 stations). No distance decay function will be applied here assuming that this distance is willingly travelled by the commuters.

The buffer size was calculated following the existing road networks for a distance of $666 \mathrm{~m}$ which corresponds to a $10 \mathrm{~min}$ walk, assuming a walking speed of $4 \mathrm{~km} / \mathrm{h}$ [56]. The buffer area was created along the existing network distance using the 'not overlapping' option, which means that discrete polygons are created for areas in which all locations are closer to the corresponding station than to any other station, as seen in Figure 2. 




Figure 2. Service area of all Bus Rapid Transit System (BRTS) stations following the road network.

\subsection{Operationalization of the Built-Form Indicators}

Indicators selected in this study are quantitative in nature, and thus each of them has a numeric value. Here, suitable measures from each built form indicator will be identified in terms of data availability and applicability. Each of the 5D measures will be calculated for each station by overlaying the 10 min walking distance buffer except for the destination accessibility measure, which needs further computation. Available measures are grouped on the basis of the literature review in the following Table 3.

Table 3. Measures for 5D indicators.

\begin{tabular}{cc}
\hline 5D (Built Form Indicators) & Popular Measures \\
\hline Density & Population density, Job density \\
Diversity & Entropy index, Dissimilarity index \\
Design & Intersection density, Street density, Link-node ratio (Beta Index/Street Connectivity Index) \\
Destination accessibility & Job accessibility by Bus Rapid Transit System (BRTS) (gravity-based measure) \\
Distance to station & Distance from nearest station (a proxy for catchment size of the stop) \\
\hline
\end{tabular}

With regards to the density measure, both density measures, population and job density, were hypothesized to be associated with boarding. In addition to density, diversity plays a crucial role in ridership as more diverse areas are expected to contribute to increased ridership. Although dissimilarity is commonly known to be a better estimator than entropy for land use diversity, the entropy index can still be contemplated for this study, because, as was already mentioned, up to a one-half mile catchment area, the entropy index can give a viable result [20]. Usually, entropy is estimated on the basis of the share (percentage) of each land use in the total area, which can also be referred to as 'land-use balance' [20]. For this study, from a set of eleven land-use categories shown on the land-use feature class, six land-use categories-commercial, industrial, institutional, residential, recreational, and mixed-use-were considered while computing the entropy index. Mixed land uses are considered for this study because a considerable number of mixed uses are apparent along the BRTS corridors. 
With regards to the design aspect, the most recommended methods for measuring road connectivity are street density and intersection density. Another measure, link-node ratio (Beta Index/Street Connectivity Index) is less intuitive because it does not reflect the length of the link. Moreover, the link-node ratio does not correspond to the actual size or spacing of the road network [20,37].

Destination accessibility was measured in terms of job accessibility by BRTS. In order to measure the job accessibility from each BRTS station, a threshold of $30 \mathrm{~min}$ travel distance travelled by BRTS was applied along the BRTS road network. This $30 \mathrm{~min}$ threshold was derived from the same BRTS user survey conducted in 2015 which reveals that almost $59 \%$ of the working trips were made with an average journey time of $30 \mathrm{~min}$ from a BRTS station to the destination BRTS station. The average speed of BRTS, $20 \mathrm{~km} / \mathrm{h}$, was applied to draw the network distance over the BRTS route.

Distance from the nearest station is usually measured considering the idea from Cervero et al. (2010) that the further a station is from the next nearest station, typically the station's catchment area increases in size [16]. However, this measure was not used for this study as the same station catchment (10 min walking distance) was already declared for all stations. Moreover, distance to transit station is not a distinguishing characteristic for a BRTS where all the stations are constructed keeping the same spacing between them just like Ahmedabad BRTS. Ahmedabad BRTS was planned and constructed with an average 500-600 $\mathrm{m}$ spacing between stations [50].

\section{Results and Discussion}

Due to data availability, the 5D indicators were measured using the variables as shown in Table 4. After determining the value for all indicators for each station catchment, their descriptive statistics such as minimum, maximum, mean, standard deviation, and skewness were tabulated to view the data distribution. Also, the discrepancy in the data like outliers was checked. Table 4 represents the descriptive statistics for the dependent variable (total monthly boarding in July 2015) and the five explanatory variables that were entered into the regression model. It is to be noted that out of 151 stations, 116 stations which had data that covered all indicators were compiled for the regression analysis.

Table 4. Descriptive statistics of all variables.

\begin{tabular}{ccccccc}
\hline Indicators & Variable & Min & Max & Mean & STDEV & Skewness \\
\hline Ridership & Boarding (July 2015) & 934 & 115,760 & 24,876 & 23,929 & 1.882 \\
\hline \multirow{2}{*}{ Density } & $\begin{array}{c}\text { Population_acre } \\
\text { Job_acre }\end{array}$ & 19 & 357 & 108 & 59 & 1.495 \\
& Intersection_acre & 0.37 & 298.83 & 46.33 & 59.05 & 2.55 \\
\hline Design & Job Accessibility by Bus Rapid & 69,631 & 495,977 & 362,698 & 100,545 & -0.969 \\
\hline Destination & Transit System (BRTS) & 0.00 & 0.76 & 0.35 & 0.18 & 0.072 \\
\hline Diversity & Entropy & & & & & 1.377 \\
\hline
\end{tabular}

All variables show skewness to some extent. Data with a positive value in skewness indicates a higher concentration of lower values in the distribution whereas negative skewness represents the opposite. For instance, job density (job per acre) showing maximum positive skewness reveals that most station catchments are having a low number of jobs while some station catchments occupy a very large number of jobs. This outcome is also consistent with the map output, shown in Figure 3, which demonstrates that $80 \%$ of the station catchments have a job density of less than 62 per acre while the other $20 \%$ are located predominantly in the eastern part with job densities up to 299 per acre. Similarly, the values for job accessibility in $30 \mathrm{~min}$ by BRTS are higher for all station catchments except the station catchments of the western periphery, as seen in Figure 4. It is quite apparent because most of the jobs are concentrated in the eastern part so that higher job accessibility can be found there. 


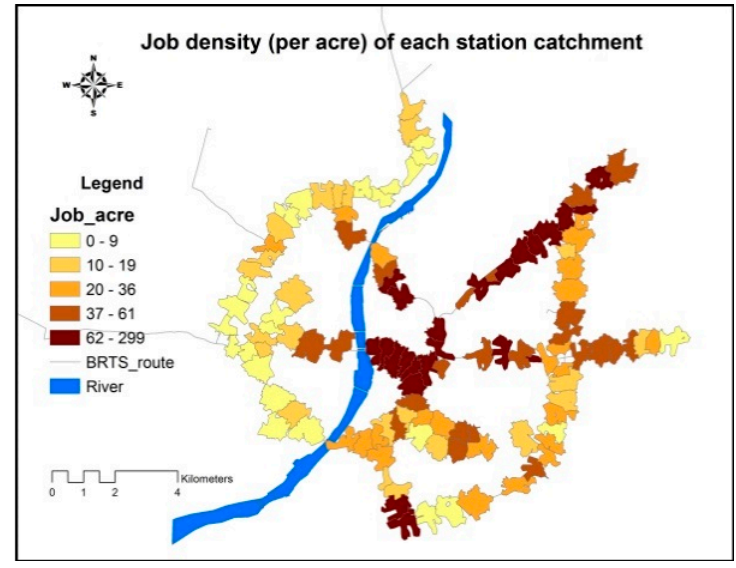

Figure 3. Job density of each station catchment.

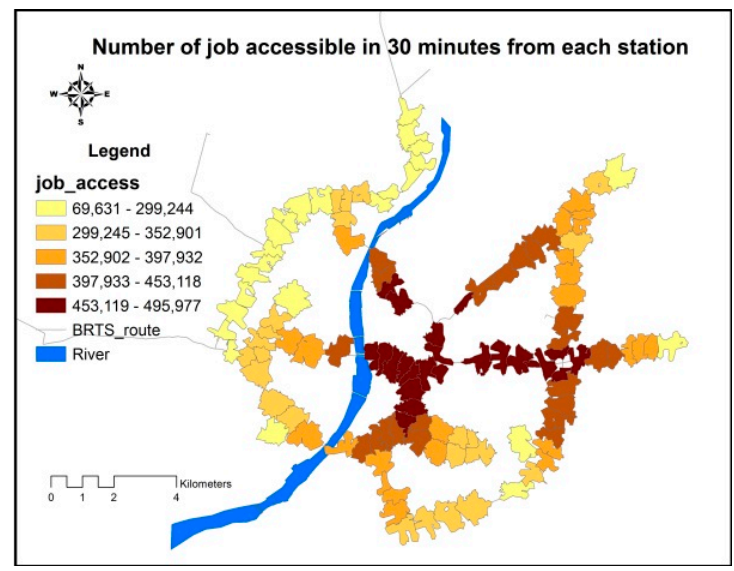

Figure 4. Job accessibility in $30 \mathrm{~min}$ of each station catchment.

Similarly, population density was found to be higher in the eastern part of Ahmedabad (see Figure 5). Shastry (2010) also found that East Ahmedabad has more densely populated areas compared to the western part of the city, which has a lower density and more dispersed residential uses [4]. Besides, Munshi (2013) also inferred that locations in East Ahmedabad where accessibility to jobs is high have a higher density of poor population (population living below the poverty line) indicating that most poor people in the city reside close to their job destinations [29].

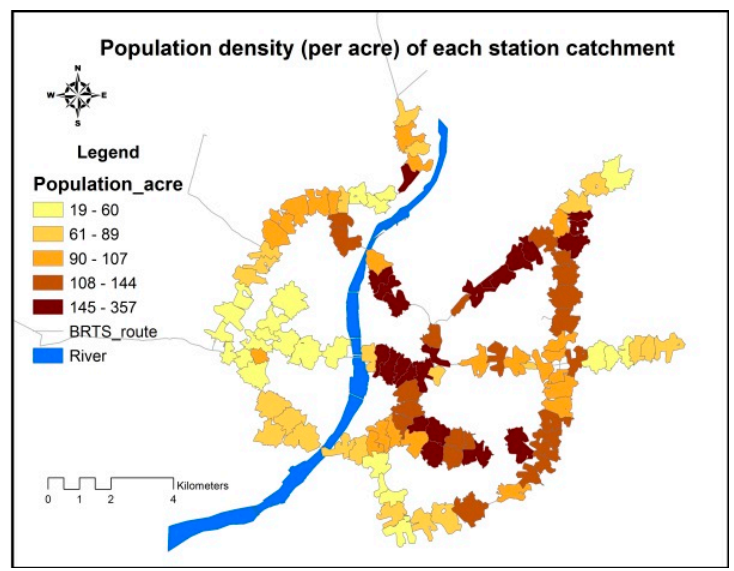

Figure 5. Population density of each station catchment. 
In terms of road connectivity, station catchments in the eastern part have relatively better connectivity than in the western part. The top $20 \%$ of the station catchments regarding road connectivity were found in both parts (east and west) of Ahmedabad, seen in Figure 6. However, using the standard of good road connectivity from Shastry (2010), it can be said that almost $96 \%$ (112 out of 116) of the station catchments along the BRTS corridors have a lower intersection density $(<0.8$ intersections per acre) which implies poor connectivity [4]. Poor connectivity of the road network would tend to reduce the ridership of BRTS.

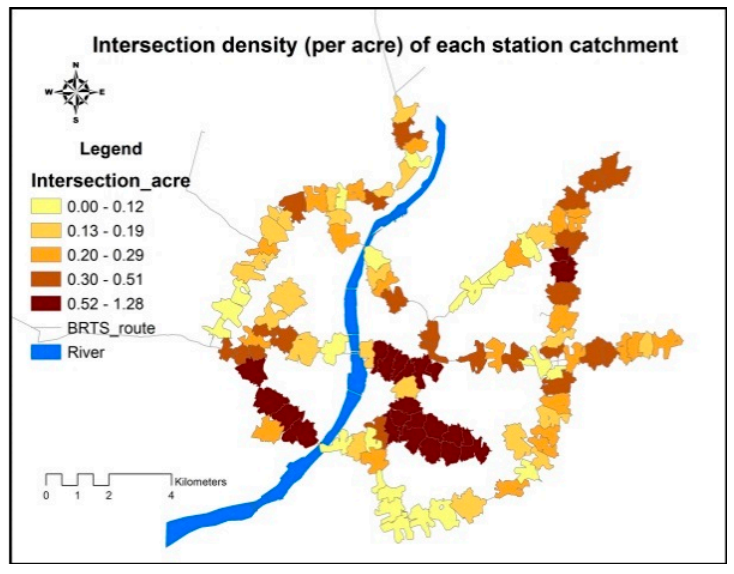

Figure 6. Intersection density of each station catchment.

Similarly, land-use diversity (entropy) along the BRTS corridors is not showing a positive result. From Figure 7, it is clear that most of the regions along the corridors are showing diversity values lower than 0.5 , which indicates homogeneity of land use and would not be supportive of enhancing ridership. Moreover, it can be concluded that the eastern part of Ahmedabad is more diverse in land-use distribution than the western part, which proves the predominance of residential use.

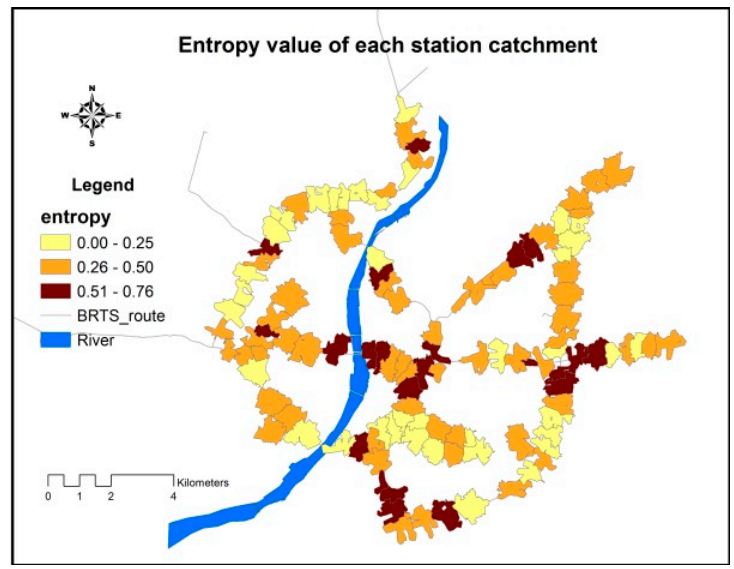

Figure 7. Entropy value of each station catchment.

On the other hand, from the distribution of total monthly boarding, shown in Figure 8, it can be said that out of 116 stations, $80 \%$ have a monthly boarding less than 40,213 while the remaining $20 \%$ of stations belong to the boarding class of $40,213-115,760$. This also reveals that stations having a higher number of boarding are mostly concentrated on the western side of Ahmedabad which is predominantly a residential use having a lower density in population and jobs. 


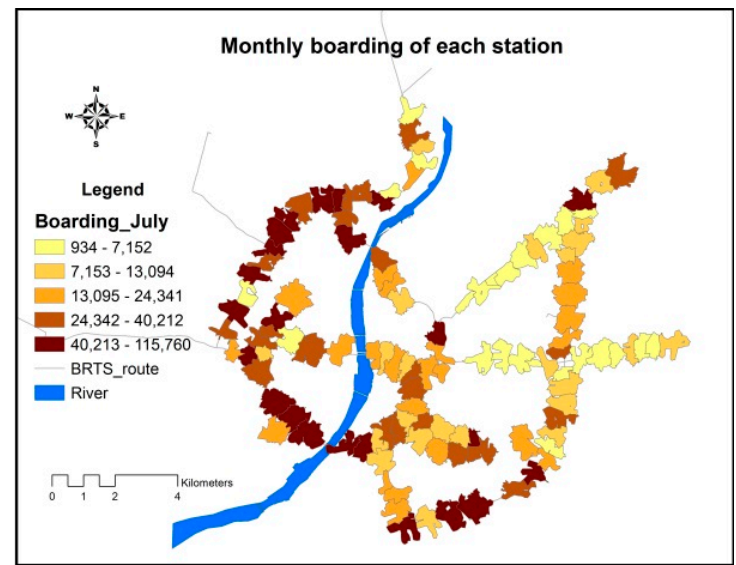

Figure 8. Monthly boarding (July 2015) of each station catchment.

In most of the studies of ridership, the multiple regression method was performed because of its capability of dealing with a large number of factors [44]. In a regression equation, a set of potential drivers of ridership are identified from the associated coefficient values. The coefficients are meant to explain the significant influence of explanatory variables on the dependent variable (ridership) [41,42]. Hensher \& Golob (2008) used Ordinary Least Square (OLS) regression model to investigate the potential drivers of BRTS ridership [41].

In order to get more insight into the influence of explanatory variables over ridership, a regression model was constructed. Prior to that, collinearity among the variables was checked. From Table 5, it is clear that there is no collinearity issue $(<0.8)$ among the independent variables. Also, it can be said that the relationship between boarding and built-form indicators is very weak, and four of them are showing a negative value, which is unexpected.

Table 5. Correlation (Pearson) among the variables.

\begin{tabular}{lcccccc}
\hline Variable & Boarding_July & Population_Acre & Job_Acre & Job_Access & Entropy & Intersection_Acre \\
\hline Boarding_July & 1 & $-0.233^{*}$ & -0.105 & $-0.301^{* *}$ & $-0.224^{*}$ & 0.007 \\
Population_acre & & 1 & $0.484^{* *}$ & $0.318^{* *}$ & -0.014 & $0.269^{* *}$ \\
Job_acre & & 1 & $0.515^{* *}$ & $0.370^{* *}$ & $0.222^{*}$ \\
Job_access & & & & 1 & $0.288^{* *}$ & $0.219^{*}$ \\
Entropy & & & & 1 & -0.150 \\
Intersection_acre & & & & & 1 \\
\hline
\end{tabular}

${ }^{*}$ Correlation is significant at the $5 \%$ level (2-tailed). ${ }^{* *}$ Correlation is significant at the $1 \%$ level (2-tailed).

In the regression model, as seen in Table 6, with the exception of intersection density other variables are statistically significant at the $5 \%$ level and the overall model is significant at the $1 \%$ level. Job density shows a positive coefficient value, while other variables reveal a negative influence on ridership. The output also implies that built-form indicators cannot explain to a substantial degree $\left(\mathrm{R}^{2}=0.17\right.$ and adjusted $\left.\mathrm{R}^{2}=0.14\right)$ the ridership of Ahmedabad BRTS. This is surprising, as it reveals a positive and significant relation between ridership and density, as was indicated earlier in various literatures shown in Table 1. In the case of Bogotá BRT study, road connectivity was found to be statistically insignificant with ridership as this variable had a little variation which is also consistent with this model [43]. 
Table 6. Regression model is predicting station boarding.

\begin{tabular}{cccccc}
\hline \multirow{2}{*}{ Model } & \multicolumn{2}{c}{ Unstandardized Coefficients } & Standardized Coefficients & \multirow{2}{*}{-Value } & \multirow{2}{*}{ Sig. } \\
\cline { 2 - 4 } & B & Std. Error & Beta & 6.96 & 0.00 \\
(Constant) & $66,420.65$ & 9547.36 & -0.28 & -2.74 & 0.01 \\
population_acre & -114.66 & 41.91 & 0.25 & 2.15 & 0.03 \\
Job_acre & 102.59 & 47.81 & 0.06 & 0.59 & 0.55 \\
Intersection_acre & 5859.81 & 9888.08 & -0.23 & -2.31 & 0.02 \\
Entropy & $-31,027.51$ & $13,429.97$ & -0.29 & -2.78 & 0.01 \\
Job_access & -0.07 & 0.02 & &
\end{tabular}

Dependent variable: Boarding_July.

To promote transit use in core urban areas, the Center for Urban Transportation Research (CUTR) at the University of South Florida (USF) recommended that population density should be higher than 85 people/acre [29]. Following this threshold, it was found that almost $39 \%$ of the station catchments are below this cut-off of population density which could have contributed to this output. Moreover, Ewing \& Cervero (2010) also did not find enough evidence to support the significant relationship of transit use (ridership) with density [37]. They computed weighted average elasticity for transit use from a set of available studies in terms of density and concluded the relationship as mostly inelastic. So it would mean that density does not always have an influence on ridership.

In terms of Floor Space Index (FSI), the land is under-utilized along the corridors of BRTS where the average utilized FSI is 0.8 with respect to the permissible FSI (2.8) [4]. One of the possible reasons behind this is that transportation plans in India are typically prepared separately from the land-use plans following only the City Development Plan [29]. The under-utilized land is more prone to dispersed and haphazard development. Cervero (2013) also argues that the reshaping of existing urban form and the land-use pattern was not a key objective of the Janmarg BRTS [57]. Janmarg was planned and designed for a mobility investment. The fact that the allowed FSI is not fully exploited along the BRTS corridors contributes to the inability of the density and diversity indicators to explain the ridership.

BRTS serves a smaller area in Ahmedabad compared to other modes such as AMTS which runs on 173 routes. This may explain that it has lower job accessibility in compared to AMTS. In terms of total job accessibility, out of 1.67 million jobs in Ahmedabad, only 0.52 million jobs can be accessible by the station catchments of BRTS. Therefore, this variable is of limited value in explaining the ridership of BRTS. In many places in Ahmedabad which have most job provisions, there is no service provided by BRTS. From the meta-study conducted by Ewing and Cervero (2010), it is known that access to jobs has the maximum influence in choosing a specific mode, which contributes to ridership of that mode [37]. So it is more likely that people will choose other operational modes rather than BRTS which are providing service in maximum job locations.

Another plausible explanation for this minimal relationship between built-form and BRTS ridership is the high travel demand of people in Ahmedabad. In a study, Mahadevia et al. (2012) pointed out that BRTS meets only $1 \%$ of travel demand of 30 billion passenger $\mathrm{km}$ [7]. So a very limited number of people are using this service. Moreover, the high fare scheme and smaller service area are driving the commuters away from BRTS. That is why this limited number of BRTS riders from each region (station catchment) are not able to make an explicit relationship with built-form. Not only income but also other socio-economic factors like automobile ownership could have effects on BRTS ridership [50]. The increase in two-wheeler (motor-scooter) ownership in Ahmedabad may also affect the performance of BRTS ridership of each station. To incorporate those variables might improve this model but they are beyond the scope of this study due to data unavailability.

Moreover, Janmarg BRTS has little variation regarding service attributes like headway, operating speed, average delay at the station, vehicle type, and capacity, so they have not been used in this model. There is no designated feeder service for Janmarg BRTS, so the majority of users access to a station 
from a 10 min walking distance. Station attributes like park and ride lot, the presence of a bus stop shelter, and the presence of bus schedule information are similar for all stations which make them less likely for use in a regression model. Station attributes like having a terminal station (end of a BRTS line) or transfer station can also explain ridership, which was found in a USA light-rail station study [44]. There are seven transfer stations in Janmarg BRTS from where people can move to anywhere respective to their destination along the BRTS route. It is more likely that people will come from further distances to get boarded in those stations to travel to their final destination. Furthermore, three railway stations and two 'GSRTC Bus Terminal' (regional bus terminal) have also been considered as transfer stations, which are mainly to facilitate intercity travel. These stations are also attracting more riders because of their locational advantages. But transfer stations account for only $8 \%$ (12 out of 151$)$ of the total stations which will not be able to explain the ridership in all stations of the Janmarg BRTS.

\section{Conclusions and Recommendations}

"The transport vision of Ahmedabad highlighted as 'Accessible Ahmedabad' aims to redesign the city structure and transportation systems towards greater accessibility, efficient mobility, and a lower carbon future" [13]. These concepts are also embedded in the National Urban Transport Policy (NUTP) of India. In a Detailed Project Report of BRTS, the focus has been given to promote Transit Oriented Development (TOD) by intensifying land along the corridors to make the city compact. It has also emphasized the promotion of non-motorized mobility with a proper facility integration for bicycles and pedestrians [12]. In support of these visions, some policy recommendation will be formulated based on the findings made from this study.

It has already been observed from studies in the USA that when development concentrates along the corridors, transit patronage increases [16,44]. However, in the Ahmedabad context, this relationship is missing, which may be due to a lack of utilization of land along the corridors. One of the recommendations that can be contemplated through this analysis is to increase the density and diversity along the BRTS corridors. An increase in density can be done by increasing the height of buildings and hence the FSI. TOD type development can be recommended along with the BRTS corridors because TOD proposes land-use mix integrated with a walkable environment to public transportation [58]. TOD can be implemented by acquiring land from the owners. However, at present, there is no mechanism developed which allows acquiring and developing the land.

Moreover, policies like zoning policies and parking policies restrict the provision of development [4]. There should be some mechanism to provide support to developers for developing land along the BRTS corridors and to create a market for this development as well. Similarly, lower intersection density along the corridors implies poor connectivity to and from BRTS stations. Proper measures also need to be considered for the implementation of safe and convenient access ways such as pedestrian ways with more than two connections in any node. These measures should be integrated with the TOD along the BRTS corridors.

The increase of accessibility to most job locations might be a possible option for BRTS ridership increase. From the expert consultation meeting with Janmarg, it is known that there is no further plan for route extension, rather they are now working solely for the improvement of accessibility to and from BRTS stations. If accessibility can be increased to a large extent from each station, there might be some potential to develop connections to important destinations and activity centers as well. In this connection, 'MYBYK' - a bike share system, an initiative by Greenpedia Bike Share Pvt. Ltd., has already been installed at 9 BRTS stations as a pilot program which will be upgraded periodically in all stations based on concurrent performance. Commuters can rent a bike at a subsidized rate to access and egress from a station. The system is not very popular yet, mostly due to a lack of infrastructure for biking. Moreover, the system is not integrated with the BRTS system in terms of fare [59]. Proper instalment of this 'bike share' system in all stations and fare integration with BRTS are therefore recommended. Possibly incentives can be provided to bike users in the form of a subsidized fare. 
These policy recommendations discussed above are general policies formulated from the research findings. No matter which strategy will be used, there is always a need of proper planning to make it successful. Besides, it requires an efficient governing body which could be formed by taking at least one representative from Ahmedabad Janmarg Limited, Ahmedabad Municipal Corporation, CEPT University, Ahmedabad Urban Development Authority and Gujarat Infrastructure Development Board. This new body will integrate decisions from all authorities in every phase of planning, designing, and implementation.

Supplementary Materials: The following are available online at http:/ /www.mdpi.com/2413-8851/2/4/95/s1.

Author Contributions: Conceptualization, M.R.I.; Data curation, M.R.I., M.B. and T.M.; Formal analysis, M.R.I.; Investigation, M.B.; Methodology, M.R.I. and M.B.; Resources, T.M.; Software, M.R.I.; Supervision, M.B. and A.G.; Writing—original draft, M.R.I.; Writing—review \& editing, M.B. and A.G.

Funding: This research received no external funding.

Acknowledgments: The authors would like to express gratitude to Shivanand Swamy from CUE for his suggestions at the time of fieldwork and especially Planning Department of CEPT University, Ahmedabad who provided us most of the latest information on Janmarg BRTS. Moreover, we would like to thank Prayag from Ahmedabad Janmarg Limited for his support in secondary data collection during fieldwork.

Conflicts of Interest: The authors declare no conflict of interest.

\section{References}

1. Deng, T.; Nelson, J.D. Bus Rapid Transit implementation in Beijing: An evaluation of performance and impacts. Res. Transp. Econ. 2013, 39, 108-113. [CrossRef]

2. Deng, T.; Ma, M.; Wang, J. Evaluation of Bus Rapid Transit Implementation in China: Current Performance and Progress. J. Urban Plan. Dev. 2013, 139, 226-234. [CrossRef]

3. Bajracharya, A.R.; Zuidgeest, M.H.P.; Brussel, M.; Munshi, T. Measurement and mapping of the impact of modal shift towards BRT in Ahmedabad. In Proceedings of the Better Air Quality (BAQ) Conference, Bangkok, Thailand, 12-14 November 2008.

4. Shastry, S. Spatial Assessment of Transit Oriented Development in Ahmedabad, India; ITC, University of Twente: Enschede, The Netherlands, 2010; Available online: http:/ / essay.utwente.nl/59707/1/MA_thesis_R_Shastry. pdf (accessed on 15 September 2015).

5. National Institute of Urban Affairs. Urban Transport Initiatives in India-Best Practices in PPP (Ahmedabad Bus Rapid Transit System). 2011. Available online: http:/ /www.niua.org/projects/tpt/AHMEDABADBRTS. pdf (accessed on 25 August 2015).

6. Mahadevia, D.; Joshi, R.; Datey, A. Low-Carbon Mobility in India and the Challenges of Social Inclusion: Bus Rapid Transit (BRT) Case Studies in India. UNEP Risø Centre on Energy, Climate and Sustainable Development, Technical University of Denmark. 2013. Available online: http:/ / www.unep.org/transport/ lowcarbon/Pdf $\backslash T 1 \backslash$ textquoterights/BRT_Casestudies_India_fullreport.pdf (accessed on 5 September 2015).

7. Mahadevia, D.; Joshi, R.; Datey, A. Accessibility and Sustainability of Bus Rapid Transit in India; Climate and Sustainable Development Technical University of Denmark: Roskilde, Denmark, 2012.

8. Rogat, J.; Dhar, S.; Joshi, R.; Mahadevia, D.; Mendoza, J.C. Sustainable Transport: BRT experiences from Mexico and India. Wiley Interdiscip. Rev. Energy Environ. 2015, 4, 564-574. [CrossRef]

9. Tiwari, G.; Mohan, D.; Rao, K.; Mahadevia, D.; Joshi, R. City Level Indicators. 2011. Available online: http:/ /www.unep.org/Transport/lowcarbon/newsletter_2/pdf/ANNEX2_City_level_Indicators_ 4oct.pdf (accessed on 9 August 2015).

10. Damor, M.N.; Kumara, S.; Hajiani, N.D. Review of Comparative study on ridership for urban mass transit systems: A case study of Ahmedabad BRTS. Int. J. Eng. Tech. Res. (IJETR) 2014, 2, 12-14.

11. Ahmedabad Municipal Corporation. Bus Rapid Transit System Plan: Phase-II Detailed Project Report. Ahmedabad, 2008. Available online: http://www.ahmedabadbrts.org/web/images/AhmedabadBRTSPhase-2DPR_April2008. pdf (accessed on 30 November 2015).

12. Ahmedabad Municipal Corporation. Executive Summary Phase 1. Ahmedabad. Available online: http://www. ahmedabadbrts.org/web/images/ExecutiveSummary_ABRTSPhase-1.pdf (accessed on 10 October 2015). 
13. Ahmedabad Municipal Corporation. Executive Summary Phase 2. Ahmedabad, 2008. Available online: http:// www.ahmedabadbrts.org/web/images/ExecutiveSummary_ABRTSPhase-2.pdf (accessed on 15 October 2015).

14. Mineta Transportation Institute. Increasing Transit Ridership: Lessons from the Most Successful Transit Systems in the 1990's; Mineta Transportation Institute: San Jose, CA, USA, 2002.

15. Transit Cooperative Reseach Program. Elements Needed to Create High Ridership Transit System; Transportation Research Board: Washington, DC, USA, 2007.

16. Cervero, R.; Murakami, J.; Miller, M. Direct Ridership Model of Bus Rapid Transit in Los Angeles County, California. Transp. Res. Rec. J. Transp. Res. Board 2010, 2145, 1-7. [CrossRef]

17. Ma, Y.-S.; Chen, X. Geographical and Statistical Analysis on the Relationship Between Land-Use Mixture and Home-Based Trip Making and More: Case of Richmond, Virginia. J. Urban Reg. Anal. 2013, 1, 5-44.

18. Stopher, P.R. Development of a route level patronage forecasting method. Transportation 1992, 19, $201-220$. [CrossRef]

19. Peng, Z.; Dueker, K.J.; Strathman, J.G.; Hopper, J. A simultaneous route-level transit patronage mode: Demand, supply, and interroute relationship. Transportation 1997, 24, 159-181. [CrossRef]

20. Cervero, R.; Kockelman, K. Travel demand and the 3Ds: Density, diversity, and design. Transp. Res. Part D Transp. Environ. 1997, 2, 199-219. [CrossRef]

21. Ewing, R.; Cervero, R. Travel and the Built Environment: A Synthesis. Transp. Res. Rec. 2001, 1780, 87-114. [CrossRef]

22. Campoli, J.; MacLean, A. Visualizing Density: A Catalog Illustrating the Density of Residential Neighborhoods; Lincoln Institute of Land Policy: Cambridge, MA, USA, 2002.

23. Kuzmyak, R.J.; Pratt, R.H. Land Use and Site Design: Traveler Response to Transport System Changes; Transit Cooperative Research Program Report 95; Transportation Research Board: Washington, DC, USA, 2003.

24. Kitamura, R.; Mokhtarian, P.L.; Laidet, L. A micro-analysis of land use and travel in five neighborhoods in the San Francisco Bay Area. Transportation 1997, 24, 125-158. [CrossRef]

25. Schwanen, T.; Dieleman, F.M.; Dijst, M. The impact of metropolitan structure on commute behavior in the Netherlands: A multilevel approach. Growth Chang. 2004, 35, 304-333. [CrossRef]

26. Stead, D. Relationships between land use, socioeconomic factors and travel patterns in Britain. Environ. Plan. B 2001, 28, 499-528. [CrossRef]

27. Cervero, R. Ridership Impacts of Transit Focused Development in California; University of California: Berkeley, CA, USA, 1993.

28. Parsons Brinckerhoff Quade \& Douglas Inc. Transit and Urban Form; Transportation Research Board, National Academy Press: Washington, DC, USA, 1996.

29. Munshi, T. Built Form, Travel Behaviour and Low Carbon Develpment in Ahmedabad, India; Urban Planning and Management, ITC, University of Twente: Enschede, The Netherlands, 2013.

30. Gao, S.; Mokhtarian, P.L.; Johnston, R.A. Exploring the connections among job accessibility, employment, income, and auto ownership using structural equation modeling. Ann. Reg. Sci. 2008, 42, 341-356. [CrossRef]

31. Lambin, E.F.; Meyfroidt, P. Global land use change, economic globalization, and the looming land scarcity. Proc. Natl. Acad. Sci. USA 2011, 108, 3465-3472. [CrossRef] [PubMed]

32. Boarnet, M.G. A Broader Context for Land Use and Travel Behavior, and a Research Agenda. J. Am. Plan. Assoc. 2011, 77, 197-213. [CrossRef]

33. Frank, L.D.; Pivo, G. Impacts of mixed use and density on utilization of three modes of travel: Single occupant vehicle, transit, and walking. Transp. Res. Rec. J. Transp. Res. Board 1994, 1466, 44-52. [CrossRef]

34. Litman, T.; Steele, R. Land Use Impacts on Transport How Land Use Factors Affect Travel Behavior. Behav. Sci. Transp. Transp. Policy 2012, 14, 269-274.

35. Dill, J. Measuring Network Connectivity for Bicycling and Walking. School of Urban Studies and Planning, Portland State University, 2004. Available online: http://reconnectingamerica.org/assets/Uploads/ TRB2004-001550.pdf (accessed on 15 December 2015).

36. Handy, S.; Paterson, R.G.; Butler, K. Planning for Street Connectivity: Getting from Here to There; Planning Advisory Service, American Planning Association: Chicago, IL, USA, 2004.

37. Ewing, R.; Cervero, R. Travel and the built environment: A meta-analysis. J. Am. Plan. Assoc. 2010, 76, $265-294$. [CrossRef]

38. Rodrigue, J.P.; Comtois, C.; Slack, B. The Geography of Transport Systems. London, 2006. Available online: https:/ / people.hofstra.edu/geotrans/eng/gallery/GeographyofTransportSystems_1ed.pdf (accessed on 10 January 2016). 
39. Owens, A.; Levinson, D. Access to Destinations: Annual Accessibility Measure for the Twin Cities Metropolitan Area; University of Minnesota: Minneapolis, MN, USA, 2012.

40. Cervero, R. Accessible Cities and Regions: A Framework for Sustainable Transport and Urbanism in the 21st Century; UC Berkeley Centre for Future Urban Transport, Institute of Transportation studies, University of California: Berkeley, CA, USA, 2005; Available online: http:/ / repositories.cdlib.org/its/futureurbantransport/vwp2005-3 (accessed on 20 January 2016).

41. Hensher, D.A.; Golob, T.F. Bus rapid transit systems: A comparative assessment. Transportation 2008, 35, 501-518. [CrossRef]

42. Hensher, D.A.; Li, Z.; Mulley, C. Drivers of bus rapid transit systems-Influences on patronage and service frequency. Res. Transp. Econ. 2014, 48, 159-165. [CrossRef]

43. Estupiñán, N.; Rodríguez, D.A. The relationship between urban form and station boardings for Bogotá's BRT. Transp. Res. Part A Policy Pract. 2008, 42, 296-306. [CrossRef]

44. Kuby, M.; Barranda, A.; Upchurch, C. Factors influencing light-rail station boardings in the United States. Transp. Res. Part A Policy Pract. 2004, 38, 223-247. [CrossRef]

45. Durning, M.; Townsend, C. Direct Ridership Model of Rail Rapid Transit Systems in Canada. Transp. Res. Rec. J. Transp. Res. Board 2015, 2537, 96-102. [CrossRef]

46. Currie, G.; Delbosc, A. Exploring Comparative Ridership Drivers of Bus Rapid Transit and Light Rail Transit Routes. J. Public Transp. 2013, 16, 47-65. [CrossRef]

47. Vergel-Tovar, E.; Rodriguez, D. The ridership performance of the built environment for BRT systems: Evidence from Latin America. J. Transp. Geogr. 2018, 1-13. [CrossRef]

48. GIDB. Bus Rapid Transit System; CEPT University: Ahmedabad, India, 2005.

49. Khanna, S. Where Are The Actual Gainers of the BRTS, Ahmedabad?" A Study into the Spatial and Social Distribution of Benefits of Transport Development Project; ITC, University of Twente: Enschede, The Netherlands, 2009.

50. Bajracharya, A.R. The Impact of Modal Shift on the Transport Ecological Footprint, A Case Study of the Proposed Bus Rapid Transit System in Ahmedabad, India; ITC, University of Twente: Enschede, The Netherlands, 2008; Available online: http:/ / www.itc.nl/library/papers_2008/msc/upm/bajracharya.pdf (accessed on 30 September 2015).

51. Hsiao, S.; Lu, J.; Sterling, J.; Weatherford, M. Use of geographic information system for analysis of transit pedestrian access. Transp. Res. Rec. 1997, 1604, 50-59. [CrossRef]

52. Levinson, H.S.; Brown-West, O. Estimating bus ridership. Transp. Res. Rec. 1984, 994, 8-12.

53. Neilson, G.; Fowler, W. Relation between transit ridership and walking distances in a low-density Florida retirement area. Highw. Res. Rec. 1972, 403, 26-34.

54. Zhao, F.; Chow, L.-F.; Li, M.-T.; Ubaka, I.; Gan, A. Forecasting transit walk accessibility: Regression model alternative to buffer method. Transp. Res. Rec. 2003, 1835, 34-41. [CrossRef]

55. Kimpel, T.J.; Dueker, K.J.; El-Geneidy, A.M. Using GIS to Measure the Effect of Overlapping Service Areas on Passenger Boardings at Bus Stops. Urisa J. 2007, 19, 5-11.

56. Guerra, E.; Cervero, R.; Tischler, D. The Half-Mile Circle: Does It Best Represent Transit Station Catchments? University of California: Berkeley, CA, USA, 2011.

57. Cervero, R. Linking urban transport and land use in developing countries. J. Transp. Land Use 2013, 6, 7-24. [CrossRef]

58. Center for Transit-Oriented Development. Transit Corridors and TOD. Available online: http://ctod.org/ pdfs/tod203.pdf (accessed on 10 December 2015).

59. MYBYK-BikeShare. Available online: http://www.mybyk.in/ (accessed on 7 February 2016).

(C) 2018 by the authors. Licensee MDPI, Basel, Switzerland. This article is an open access article distributed under the terms and conditions of the Creative Commons Attribution (CC BY) license (http://creativecommons.org/licenses/by/4.0/). 